This item is the archived peer-reviewed author-version of:

Seaport CSR : innovation for economic, social and environmental objectives

\title{
Reference:
}

Vanelslander Thierry.- Seaport CSR : innovation for economic, social and environmental objectives

Social responsibility journal - ISSN 1747-1117 - 12:2(2016), p. 382-396

Full text (Publisher's DOI): https://doi.org/10.1108/SRJ-05-2014-0066

To cite this reference: $\mathrm{http}: / /$ hdl.handle.net/10067/1329170151162165141 


\section{SEAPORT CSR: INNOVATION FOR ECONOMIC, SOCIAL AND ENVIRONMENTAL OBJECTIVES}

\section{INTRODUCTION: OBJECTIVES AND METHODOLOGY}

Till now, corporate social responsibility (CSR) in seaports has not really received visible attention in academic literature. That is in contrast to wider applications of CSR research to other economic sectors (see e.g. Malik, 2013), and also in general business practice, as CSR is a concept that was introduced in the early seventies. Certain aspects do get attention though, in a fragmented way, in the recent literature related to ports. It can be derived as a common denominator from the wider academic CSR literature that CSR covers three main fields: economic, social and environmental issues. Environmental sub-issues for instance lately covered in seaport-related research involve port pollution (e.g. Homsombat et al., 2013) and clean hinterland transport (e.g. Clott and Hartmann, 2013). Environmental management or measurement in seaports is also treated more generally (e.g. Chang, 2013). Economic issues have been dealt with for most long, under the umbrellas of for instance port efficiency (e.g. Felicio and Calderinho, 2013; Lee et al., 2013; Schoyen and Odeck, 2013; Barros et al., 2012) or port hinterland optimisation (e.g. lannone, 2013). The social aspect clearly has been underperforming as to academic literature attention.

Hardly ever in port-related literature has an integration of the analyses from different categories of issues been performed. Two of the only recent academic references combining economic and environmental objectives are Haralambides and Gujar (2013) and Lam and Gu (2013). For that reason, there is no real view on the extent to which CSR is actually on the agenda in seaports, and how that is done.

This paper tries to provide some answer to that lack in academic literature, by testing the presence and success of CSR in the port sector. The objective is then to test what type of innovation initiatives are typically taken from a CSR viewpoint in seaports, what the main goals are that are aimed for, and to what extent these goals are actually being achieved by the CSR initiatives. A case study is made to two ports (Antwerp and Rotterdam) and a comprehensive set of innovation initiatives. In order to reach the above-stated objective, a methodology consisting of two broad steps is applied, with sub-steps to be taken. That also determines the further structure of the paper.

First, literature research is conducted, with the aim of finding a common definition of CSR, and in particular a common 'CSR measurement system'. To 
do that, both academic and policy literature is consulted, all of them international. The overview of the literature and derived observations is presented in section 2.1. Out of that search comes a split up of goals and subgoals in three main fields, represented by indicators each time. The resulting scheme is input to the work of the next sub-section.

Next, a Delphi exercise is conducted among the selected port-related companies. With that exercise, starting from the objective scheme developed through the literature search, the scheme is submitted to seven private and public companies active in the ports of Antwerp and/or Rotterdam and featuring a clear CSR policy, for their suggestions on correction and improvement. The companies belong to different business activities, that all have a clear link with the port: DAB Vloot, Air Liquide, Jan De Nul Group, BASF, Port of Rotterdam, Total and Hydrex. Their nature and characteristics will be made further explicit in section 2.2. The feedback is gained twice from the companies: first to get feedback on the scheme resulting from section 2 , and a second time to get feedback on an updated scheme after the first round of company questioning. The scheme resulting from that analysis is presented in section 2.3.

Further on, a scoring is asked from the companies on the extent to which the specific goals and subgoals are relevant to them in conducting their CSR policies. That scoring is presented in section 2.4. A 'yes' or 'no' system is applied to detect relevance, as a pilot interview showed that having further differentiation led to inconsistent scorings.

Then the paper turns to a specific innovation that is selected for each of the seven companies. The innovations are identified as key to the companies, and are described in section 3.1. The companies were then asked to score the innovations on their materialized impact on the various goals and subgoals. Section 3.2 presents the results of the scoring, and analyses the innovations apparently performing best.

Section 4 then checks the consistency between the importance of the various CSR goals, and the degree of success in contributing to that objective through the selected innovation. To do that, the degree of homogeneity of both the objective scoring and the innovation scoring are determined, and those two are then compared.

Finally, in section 5, conclusions are drawn, and suggestions for further research are indicated. 


\section{CORPORATE SOCIAL RESPONSIBILITY OBJECTIVES}

\subsection{CSR BACKGROUND AND LITERATURE REVIEW}

In 1976, the OECD introduced its Guidelines for Multinational Enterprises. The Guidelines have always been meant to function as the leading international instrument for the promotion of responsible business conduct. These were reviewed five times in the meantime, and in 2011 for the last time. The most recent changes include the introduction of a human rights chapter, a new approach to due diligence and responsible supply chain management, and updates with respect to employment, environment, bribery, consumer interests and taxation issues. The updates were checked with a wide group of stakeholders, exceeding by far the own OECD members. (OECD, 2011)

Younger, but according to its own saying the largest voluntary corporate responsibility initiative in the world, with over 10,000 corporate participants and other stakeholders from over 130 countries, is the UN Global Compact (United Nations Global Compact Office, 2010). It is a strategic policy initiative for businesses that are committed to aligning their operations and strategies with ten universally accepted principles, relating to human rights, labour, environment and anti-corruption. Overall, the UN Global Compact deals with highly similar issues as does OECD. Largely, the Compact is in line with the UN's Guiding Principles on Business and Human Rights.

The European Commission introduced a definition of CSR as they would like to see it applied by companies active in Europe. They define CSR as "the responsibility of enterprises for their impacts on society" (European Commission, 2011, p. 6). The definition gets translated in an action plan, running from 2011 to 2014. The action plan has following purposes: enhancing the visibility of CSR and disseminating good practices, improving and tracking levels of trust in business, improving self- and co-regulation processes, enhancing market reward for CSR, improving company disclosure of social and environmental information, further integrating CSR into education, training and research, and emphasising the importance of national and sub-national CSR policies. The European CSR policy is aligned with the above-mentioned initiatives, and with the ILO Tri-partite Declaration of Principles on Multinational Enterprises and Social Policy.

The International Standardization Organization developed the ISO 26000 scheme for Social Responsibility, which, in contrast to other ISO certification schemes, provides guidelines rather than requirements. The latter involve human rights, labour practices, environment, fair operating practices, 
consumer issues and community involvement and development. The guidelines were developed in 2010. (International Organization for Standardization, 2013).

None of the above-mentioned sources seem to offer an operational checking scheme with defined CSR objectives or measures. The Dutch Stichting Stimular (2013), focusing on companies operating in a sustainable way, did so. Its 'MVO-balans', a checklist on CSR, covers three main fields: economic, social and environmental objectives. The economic component is composed of a return item, and a chain one. The social component involves a security item, and a societal one. Their checklist is taken as a start for the analysis in this paper.

In the academic literature, Abreu and Barlow (2013) take a wide approach, comparing internationally the CSR approaches and objectives of leading companies. Recent work by El Ebrashi (2011) is useful with respect to social objectives. Leite and Padgett (2011) show how CSR over time has evolved from doing charity to society, over attention to social changes and challenges, to business strategies encompassing a wider set of goals. With economic and financial arguments in mind due to the 2008 economic and financial crisis, the approach and findings of Lauesen (2012) are relevant. Finally, Gill (2012) provides interesting perspectives on environmental responsibility. Additions, qualifications and modifications are made to the Dutch Stichting Stimular's objectives checklist with the help of the above-mentioned academic literature.

In the next section, the companies are shown to which the objectives were submitted for a Delphi analysis. The resulting items and their concrete objectives, starting from the modified Dutch Stichting Stimular's CSR checklist, are presented in section 2.3.

\subsection{SELECTED COMPANIES}

The selection of port-related companies, two whom the literature list of CSR objectives was submitted, is on purpose mixed, reflecting the diversity of activities present in seaport areas, and being representative for the large sectors generating employment, value added and investments in the port. The companies are briefly described below, to show their characteristics and linkage with ports.

\section{DAB Vloot}


DAB Vloot is a sub-entity of the Flemish Government, in charge of managing the region's sea-going vessels, 45 in total, used for pilotage, hydrography, beaconing, patrolling, customs, salvage, research, towage and ferrying. Its territory is the North Sea, the river Scheldt, two docks in the ports of Antwerp and Ghent respectively, and one inland waterway stretch.

\section{Air Liquide}

Air Liquide is a French multinational, world leader in the delivery of industrial and medical gases, and ancillary services. The company is active in 80 countries and quoted on the Euronext stock market. In Belgium, the company has about 25,000 customers, served through 250 depots.

\section{Jan De Nul Group}

Jan De Nul Group is a Belgian company, mainly known as one of the four core dredging companies in the world, but also active in civil construction and environmental engineering. Its dredging activities involve seaports, channels, and sandbanks at full sea. Furthermore, also off-shore activities are performed. Civil works comprise public and private construction. Soil and soil water sanitation compose a third activity. Among the projects are the widening of the Panama Canal and the construction of the dredging waste site Amoras in Antwerp.

\section{BASF}

BASF is world leader in the chemical market. BASF Antwerp is Belgium's largest integrated chemical production centre, and the group's second largest production platform behind Ludgwishafen am Rhein. BASF offers a range of products, from plant protection and feeding, chemical product, synthetics and fibres, colour and grading up products, to oil and gas.

\section{The Port of Rotterdam}

The Port of Rotterdam is the biggest port in Europe, and the third port globally. In containers, its largest commodity group, the port is ranked 10th globally. It is strategically located at full sea at relatively close distance of the large Western-European hinterland. The Port of Rotterdam is an independent public limited company, not quoted on the stock exchange, but with two shareholders: the City of Rotterdam and the Dutch State. The Port has a landlord nature, but also performs functions as a regulator and operator. It rents out land under concession to operators inside the port. 


\section{Total}

Total is a French petrol distributor founded in 1924, having grown enormously through the takeovers of Petrofina (1999) and Elf Aquitaine (2000). Through that expansion, the group is the world's fifth largest player in the market. The company is active both upstream (detecting oil stocks) and downstream (refinery and distribution). Total's most complex refinery, and actually the second largest refinery overall in Europe, is located in the port of Antwerp.

\section{Hydrex}

Hydrex was founded in 1974 and is known for underwater repair and replacements. One of the key developments is to improve ships' hull performance, so as to optimize ship performance. In the meantime, the company received various international awards in recognition of their inventions and sustainable alternatives.

\subsection{CSR OBJECTIVES RESULTING FROM LITERATURE AND COMPANY REVIEW}

This section summarizes the objectives as resulting from the literature review and the company assessment.

\section{Economic CSR objectives}

Economic return objectives encompass the classical financial ratios, supplemented with the cost of material inputs and transport (table 1). On the product side, sustainability is considered both on the selling and purchasing side.

Table 1: Selected economic CSR objectives

$\square$ Return

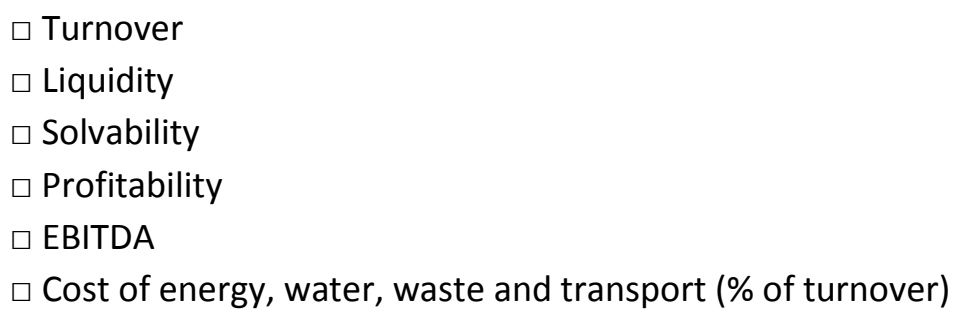

$\square$ Sustainable purchasing 
$\square$ Purchasing costs of raw materials $\mathrm{x}$ or material y per euro of turnover

$\square$ Percentage of purchasing budget in which environmental and social criteria are assumed

$\square$ Percentage of suppliers and service providers with whom agreements are made about environmental and social affairs $\square$ Share of purchased raw materials that is judged on presence of dangerous products

Source: own composition

\section{Social CSR objectives}

Social return objectives involve mainly security and well-being, of which training is an important aspect (table 2).

Table 2: Selected social CSR objectives

$\square$ Security

$\square$ Healthy employees

$\square$ Number of (near-)accidents without personal damage

$\square$ Number of accidents with personal damage

$\square$ Number of accidents with work leave

$\square$ Number of dangerous goods in the company

$\square$ Number of IMO containers

$\square$ Number of improvement points from the annual RI\&E

$\square$ Number of environmental incidents

$\square$ Percentage of short leave

$\square$ Percentage of medium leave

$\square$ Percentage of long leave

$\square$ Happy employees

$\square$ Happiness of employees

$\square$ Percentage of staff turnover

$\square$ Employee training

$\square$ Share of number of hours of training (\% of company hours)

$\square$ Share of number of hours of training focused on sustainability

(\% of company hours)

$\square$ Share of training costs in total company costs

$\square$ Percentage of employees that follows individual training

$\square$ Employee diversity

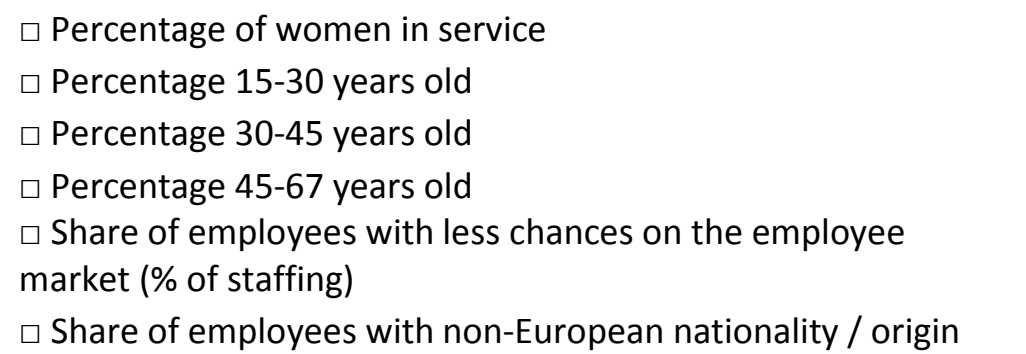


$\square$ Society

$\square$ Share of local suppliers and/or providers (within a range of $x$ kilometres)

$\square$ Number of complaints about nuisance

$\square$ Share of employees that contribute to annual volunteer activities of the company

$\square$ Share of supplied capital, facilities and human power for sustainable goals (\% of turnover)

$\square$ Share of internship and training places (\% of staffing)

Source: own composition

\section{Environmental CSR objectives}

On the environmental side, energy, climate and waste are involved (table 3).

Table 3: Selected environmental CSR objectives

$\square$ Energy and climate

$\square$ Waste

$\square$ Traffic and transport

\author{
$\square$ Electricity usage \\ $\square$ Percentage sustainably developed electricity \\ $\square$ Percentage sustainably developed heat \\ $\square$ Gas or water usage \\ $\square \mathrm{CO}_{2}$ emission
}

$\square$ Waste separation / reycling share

$\square$ Total waste per employee

$\square$ Fuel usage business traffic per EURO of turnover

$\square$ Percentage of company cars with label A or B

$\square$ Fuel usage of freight trucks per EURO turnover

$\square$ Percentage of freight trucks with at least EURO 5 engines

$\square$ Home-work kilometres per employee

$\square$ Percentage public transport and bike in home-work transport

$\square$ Share of home work

$\square$ Promoting expenses for using public transport

Source: own composition

\subsection{IMPORTANCE OF THE RESPECTIVE CSR OBJECTIVES}

As part of the Delphi exercise, the selected companies were asked to score the CSR objectives on their relevance to the company's CSR policy. Their scores can be found in table 4, where the column ' 0 ' indicates the share of respondents that found the specific objective irrelevant within their CSR policy, whereas ' 1 ' mirrors the share of respondents attaching relevance to the objective.

It is found that overall, social objectives are deemed most relevant (average score $51 \%$, mean $57 \%$ ), followed by economic objectives (average score 
$47 \%$, mean $43 \%$ ), and with environmental objectives being least important (average score $39 \%$, mean $29 \%$ ). In all, the most relevant objectives turn out to be turnover (economic) and $\mathrm{CO}_{2}$ emissions (environmental). Judged irrelevant with respect to their CSR policies are the 'percentage of purchasing budget in which environmental and social criteria are assumed', 'number of improvement points from the annual RI\&E', 'share of employees with less chances on the employee market (\% of staffing)', 'share of local suppliers and/or providers (within a range of $x$ kilometres)', and 'fuel usage of freight trucks per EURO turnover'.

Table 4: Importance of the selected CSR objectives

Main

objective

Economic

$\square$ Return

$\square$ Turnover

$\square$ Liquidity

$\square$ Solvability

$\square$ Profitability

$\square$ EBITDA

$\square$ Cost of energy, water, waste and transport (\% of turnover)

$\square$ Selling sustainable products/services

$\square$ Percentage offers with sustainable options

$\square$ Share of sustainable products or services in the assortment

$\square$ Percentage of turnover related to sustainable products or services

$\square$ Share of complaints about products and services

$\square$ Sustainable purchasing

$\square$ Purchasing costs of raw materials $\mathrm{x}$ or material y per euro of turnover

$\square$ Percentage of purchasing budget in which environmental and social criteria are assumed

$\square$ Percentage of suppliers and service providers with whom agreements are made about environmental and social affairs

$\square$ Share of purchased raw materials that is judged on

presence of dangerous products

Social

$\square$ Security
$0 \quad 1$

$\begin{array}{rr}0 \% & 100 \% \\ 14 \% & 86 \% \\ 14 \% & 86 \% \\ 29 \% & 71 \% \\ 29 \% & 71 \% \\ 57 \% & 43 \%\end{array}$

$86 \% \quad 14 \%$

$71 \% \quad 29 \%$

$86 \% \quad 14 \%$

$43 \% \quad 57 \%$

$86 \% \quad 14 \%$

$100 \% \quad 0 \%$

$71 \% \quad 29 \%$

$57 \% \quad 43 \%$

$57 \% \quad 43 \%$

$14 \% \quad 86 \%$

$29 \% \quad 71 \%$

$43 \% \quad 57 \%$

$86 \% \quad 14 \%$

$100 \% \quad 0 \%$

$43 \% \quad 57 \%$ 
$\square$ Healthy employees

$$
\square \text { Percentage of short leave }
$$

$\square$ Happy employees

$$
\square \text { Happiness of employees }
$$

$\square$ Employee training

$\square$ Share of number of hours of training (\% of company hours)

$\square$ Share of number of hours of training focused on sustainability (\% of company hours)

$\square$ Share of training costs in total company costs

$\square$ Percentage of employees that follows individual training

$\square$ Employee diversity

$$
\begin{aligned}
& \square \text { Percentage of women in service } \\
& \square \text { Percentage } 15-30 \text { years old } \\
& \square \text { Percentage } 30-45 \text { years old } \\
& \square \text { Percentage } 45-67 \text { years old } \\
& \square \text { Share of employees with less chances on the } \\
& \text { employee market (\% of staffing) } \\
& \square \text { Share of employees with non-European nationality / } \\
& \text { origin }
\end{aligned}
$$

$\square$ Society

$\square$ Share of local suppliers and/or providers (within a range of $x$ kilometres)

$\square$ Number of complaints about nuisance

$\square$ Share of employees that contribute to annual volunteer activities of the company

$\square$ Share of supplied capital, facilities and human power for sustainable goals (\% of turnover)

Environmental

$\square$ Energy and climate

$$
\begin{aligned}
& \square \text { Electricity usage } \\
& \square \text { Percentage sustainably developed electricity } \\
& \square \text { Percentage sustainably developed heat } \\
& \square \text { Gas or water usage } \\
& \square \mathrm{CO}_{2} \text { emission }
\end{aligned}
$$

$\square$ Waste

$\begin{array}{lll}\square \text { Waste separation / reycling share } & 57 \% & 43 \% \\ \square \text { Total waste per employee } & 57 \% & 43 \%\end{array}$

$\square$ Traffic and transport

$\begin{array}{lrr}\square \text { Fuel usage business traffic per EURO of turnover } & 71 \% & 29 \% \\ \square \text { Percentage of company cars with label A or B } & 86 \% & 14 \% \\ \square \text { Fuel usage of freight trucks per EURO turnover } & 100 \% & 0 \% \\ \square \text { Percentage of freight trucks with at least EURO } 5 & 86 \% & 14 \%\end{array}$




\section{engines}

$\square$ Home-work kilometres per employee $\quad 71 \%$

$\square$ Percentage public transport and bike in home-

work transport

$\square$ Share of home work

Source: own composition

$\square$ Promoting expenses for using public transport

$71 \%$

$29 \%$

\section{PORT INNOVATION INITIATIVES IN CSR}

This section subsequently introduces the innovation initiatives that will be used in the test, and the scores obtained as to how well the initiatives contribute to obtaining the various sub-objectives.

\subsection{INNOVATION CASES}

For each of the companies dealt with in the previous section, one innovation was selected, for which the CSR impact will further on be tested. The selected innovation actions are described below. They compose a mixture of more technological and more process-oriented innovation initiatives.

\section{DAB Vloot: SWATH vessels}

SWATH stands for 'Small Waterplane Area Twin Hull' ship. It is a vessel type that has two hulls, and through that combines a minimum contact area with the waterline with a maximum stability, thereby not suffering from tidal impacts, and being able to reach high speeds, also in very bad weather conditions.

\section{Air Liquide: safety innovation}

Improving safety has become a key point for Air Liquide, and can therefore be considered a process innovation within the company, both for employees and subcontractors. In 2005, the company launched its 'Industrial Management System'. Key features of the vision behind are: prevention, protection, early detection and quick action. The process involves a risk analysis and an awareness campaign. In 2012, Air Liquide Belux was the pilot entity within the group for the 'Life Savings Rules' project, within which employees have to respect 12 key rules, under threat of dismissal.

\section{Jan De Nul Group: Simon Stevin}

Simon Stevin is Jan De Nul's largest fall pipe and mining vessel, acquired 2010. It can carry 35,000 tonnes, process 2,000 tonnes per hour, and is meant to do rock deposits at high depth (up to $2,000 \mathrm{~m}$ ). 


\section{BASF: water cleaning}

In chemical processes, quite some water is used, which contains pollutants, hence cannot be disposed of directly in nature. Water clearing happens in four steps: (i) sifting and neutralizing, (ii) aerofication, (iii) slib sinking, (iv) covering and resting.

\section{The Port of Rotterdam: Plant One}

The innovation considered for the Port of Rotterdam is Plant One, a test facility for sustainable and innovative process technologies, founded by the Port, together with Deltalings (the private port operators' association), TNO (the Dutch official research institute) and Rotterdam World Climate Initiative. The aim is to function as a link between laboratory and real-life application. Doing so should contribute to the Port's ambition to reduce $\mathrm{CO}_{2}$ emissions by $50 \%$ by 2025, as compared to 1990 .

\section{Total: reducing dock spills}

One of the key innovation projects within Total is reducing oil spills when transferring oil between modes. The project is split up in six phases, five of which have been run through by now. One of the shifts is from passive to active securitization. That implies that operators need to perform an attendance confirmation every 10 minutes. Furthermore, vapor recovery is performed, in a specific unit, that allows reusing emitted vapors.

\section{Hydrex: Ecospeed}

Ecospeed is a hard, inert coating, used for vessel hulls. Advantages are the absence of damage, no release of harmful products, and the possibility of cleaning under water, which increases the speed by which operations can happen. Ecospeed has a life expectancy of 25 years, and has anti-corrosive properties.

\subsection{INNOVATION IMPACT SCORING}

This section presents the scoring given by the seven operators on how well they achieve the various objectives. A 3-point scale is applied, where ' 0 ' means no achievement at all, whereas ' 3 ' means very satisfactory achievement (table 5). It seems that the social objectives are best being achieved, followed by economic and environmental objectives. This is in line with the relative importance of the three types of objectives, as analysed in section 2.4. Best achievable seem the 'number of dangerous goods', 'share of 
number of hours of training' and 'percentage of employees that follows individual training'. Of the latter, only the 'share of number of hours of training' was deemed very relevant by the companies, as resulting from section 2.4. Of the objectives judged overall very important as in section 2.4 , only ' $\mathrm{CO}_{2}$ emissions' seems to be very well achieved through innovation initiatives.

Table 5: Innovation success scores

\section{Main objective}

Economic

$\square$ Return

$\square$ Turnover
$\square$ Liquidity
$\square$ Solvability
$\square$ Profitability
$\square$ EBITDA
$\square$ Cost of energy, water, waste and
transport (\% of turnover)

$\square$ Selling sustainable products/services

$\square$ Percentage offers with sustainable options

$\square$ Share of sustainable products or services in the assortment

$\square$ Percentage of turnover related to sustainable products or services

$\square$ Share of complaints about products and services

$\square$ Sustainable purchasing

$\square$ Purchasing costs of raw materials $x$ or material y per euro of turnover

$\square$ Percentage of purchasing budget in which environmental and social criteria are assumed

$\square$ Percentage of suppliers and service providers with whom agreements are made about environmental and social affairs

$\square$ Share of purchased raw materials that is judged on presence of dangerous products

Social

$\square$ Security

$\square$ Number of (near-)accidents without personal damage

$\square$ Number of accidents with personal

damage

$\square$ Number of accidents with work leave
0

1

2

3

$\begin{array}{rrrr}0 \% & 29 \% & 43 \% & 29 \% \\ 43 \% & 14 \% & 0 \% & 0 \% \\ 43 \% & 14 \% & 0 \% & 0 \% \\ 29 \% & 14 \% & 0 \% & 0 \% \\ 29 \% & 14 \% & 0 \% & 0 \% \\ 43 \% & 29 \% & 29 \% & 29 \% \\ & & & \\ & & & \\ 86 \% & 14 \% & 0 \% & 0 \% \\ 43 \% & 29 \% & 14 \% & 14 \% \\ 71 \% & 14 \% & 14 \% & 0 \% \\ 43 \% & 14 \% & 29 \% & 14 \%\end{array}$

$86 \%$

$0 \% \quad 14 \%$

$0 \%$

$86 \% \quad 14 \% \quad 0 \% \quad 0 \%$

$57 \% \quad 29 \% \quad 14 \% \quad 0 \%$

$57 \% \quad 14 \% \quad 14 \% \quad 14 \%$

$\begin{array}{llll}29 \% & 29 \% & 29 \% & 14 \% \\ 14 \% & 29 \% & 29 \% & 29 \% \\ 29 \% & 14 \% & 29 \% & \end{array}$


$\square$ Number of dangerous goods

$\square$ Number of IMO containers

$\square$ Number of improvement points from the annual RI\&E

$\square$ Number of environmental incidents

$\square$ Healthy employees

$\square$ Percentage of short leave

$\square$ Percentage of medium leave

$\square$ Percentage of long leave

$\square$ Happy employees

$$
\begin{aligned}
& \square \text { Happiness of employees } \\
& \square \text { Percentage of staff turnover }
\end{aligned}
$$

$\square$ Employee training

$\square$ Share of number of hours of training (\% of company hours)

$\square$ Share of number of hours of training focused on sustainability

(\% of company hours)

$\square$ Share of training costs in total company costs

$\square$ Percentage of employees that follows individual training

$\square$ Employee diversity

$\square$ Percentage of women in service
$\square$ Percentage $15-30$ years old
$\square$ Percentage $30-45$ years old
$\square$ Percentage $45-67$ years old
$\square$ Share of employees with less
chances on the employee market (\%
of staffing)
$\square$ Share of employees with non-
European nationality / origin

$\square$ Society

$\square$ Share of local suppliers and/or providers (within a range of $x$ kilometres)

$\square$ Number of complaints about nuisance

$\square$ Share of employees that contribute to annual volunteer activities of the company

$\square$ Share of supplied capital, facilities and human power for sustainable goals (\% of turnover)

$\square$ Share of internship and training places (\% of staffing)

$\begin{array}{rrrr}43 \% & 14 \% & 0 \% & 43 \% \\ 86 \% & 14 \% & 0 \% & 0 \% \\ 100 \% & 0 \% & 0 \% & 0 \% \\ 43 \% & 0 \% & 0 \% & 29 \% \\ & & & \\ 43 \% & 14 \% & 29 \% & 14 \% \\ 43 \% & 14 \% & 29 \% & 14 \% \\ 43 \% & 29 \% & 29 \% & 0 \%\end{array}$

$29 \% \quad 29 \% \quad 43 \% \quad 0 \%$

$71 \% \quad 14 \% \quad 14 \% \quad 0 \%$

$29 \% \quad 0 \% \quad 29 \% \quad 43 \%$

$14 \% \quad 29 \% \quad 29 \% \quad 29 \%$

$29 \% \quad 14 \% \quad 43 \% \quad 14 \%$

$43 \% \quad 0 \% \quad 14 \% \quad 43 \%$

$\begin{array}{llll}43 \% & 57 \% & 0 \% & 0 \%\end{array}$

$43 \% \quad 43 \% \quad 14 \% \quad 0 \%$

$43 \% \quad 29 \% \quad 29 \% \quad 0 \%$

$43 \% \quad 29 \% \quad 29 \% \quad 0 \%$

$86 \% \quad 14 \% \quad 0 \% \quad 0 \%$

$57 \% \quad 14 \% \quad 29 \% \quad 0 \%$

$100 \% \quad 0 \% \quad 0 \% \quad 0 \%$

$43 \% \quad 0 \% \quad 29 \% \quad 29 \%$

$100 \% \quad 0 \% \quad 0 \% \quad 0 \%$

$57 \% \quad 43 \% \quad 0 \% \quad 0 \%$

$43 \% \quad 0 \% \quad 43 \% \quad 14 \%$

Environmental 
$\square$ Energy and climate

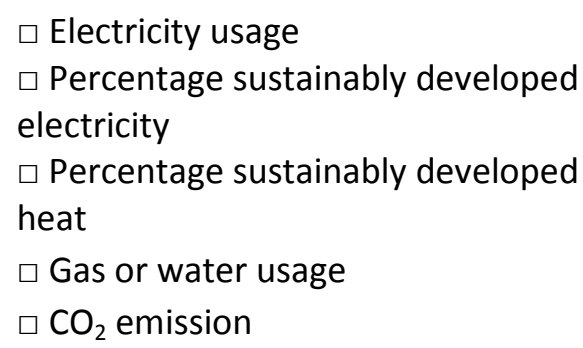

$\square$ Waste

$$
\begin{aligned}
& \square \text { Waste separation / reycling share } \\
& \square \text { Total waste per employee }
\end{aligned}
$$

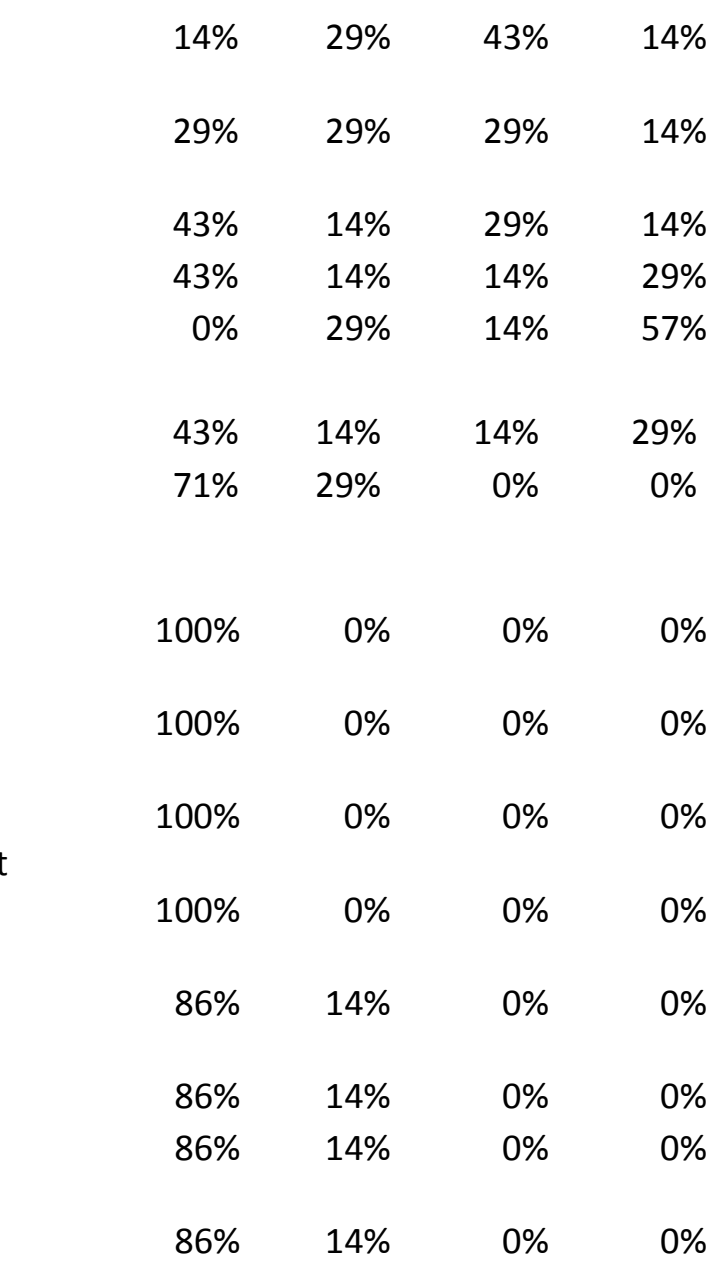

$\square$ Traffic and transport

$$
\begin{aligned}
& \square \text { Fuel usage business traffic per } \\
& \text { EURO of turnover } \\
& \square \text { Percentage of company cars with } \\
& \text { label A or B } \\
& \square \text { Fuel usage of freight trucks per } \\
& \text { EURO turnover } \\
& \square \text { Percentage of freight trucks with at } \\
& \text { least EURO } 5 \text { engines } \\
& \square \text { Home-work kilometres per } \\
& \text { employee } \\
& \square \text { Percentage public transport and } \\
& \text { bike in home-work transport } \\
& \square \text { Share of home work } \\
& \square \text { Promoting expenses for using } \\
& \text { public transport }
\end{aligned}
$$

Source: own composition

\section{OBJECTIVE IMPORTANCE VERSUS INNOVATION SUCCESS}

This section compares the objective importance with the innovation success. It therefore first calculates a homogeneity index. It does so by calculating the squared sum of shares of the various possible replies, both for the objective relevance and the innovation success:

$$
h_{i}=\sum_{j} f_{i j}^{2}
$$

Out of that $\mathrm{h}$ value, a homogeneity index is derived, by applying the below formula for objective scoring:

$$
H_{i}=\frac{h_{i}-\min \left(h_{i}\right)}{\max \left(h_{i}\right)-\min \left(h_{i}\right)}=\frac{h_{i}-0.50}{0.50}
$$

For the innovation success scoring, the below formula results: 


$$
H_{i}=\frac{h_{i}-\min \left(h_{i}\right)}{\max \left(h_{i}\right)-\min \left(h_{i}\right)}=\frac{h_{i}-0.25}{0.75}
$$

A high $\mathrm{H}$ value is an indication of homogenous answers by the respondents, whereas a low value indicates dispersion in the answers. For the objective relevance $(\mathrm{H}$ obj), full homogeneity is found for 'turnover', 'percentage of purchasing budget in which environmental and social criteria are assumed', 'number of improvement points from the annual RI\&E', 'share of employees with less chances on the employee market', 'share of local suppliers and/or providers', ' $\mathrm{CO}_{2}$ emission', and 'fuel usage of freight trucks per EURO turnover' (table 6). Of the latter, only 'number of improvement points from the annual RI\&E', 'share of local suppliers and/or providers' and 'fuel usage of freight trucks per EURO turnover' do feature full homogeneity as to innovation success scores ( $\mathrm{H}$ inno).

Table 6: Homogeneity scores for objective relevance and innovation success

\begin{tabular}{|c|c|c|c|}
\hline $\begin{array}{c}\text { Main } \\
\text { objective }\end{array}$ & Sub-objective & $\begin{array}{c}\mathrm{H} \\
\text { object }\end{array}$ & $\begin{array}{c}\mathrm{H} \\
\text { inno }\end{array}$ \\
\hline \multicolumn{4}{|l|}{ Economic } \\
\hline \multicolumn{4}{|l|}{$\square$ Return } \\
\hline & $\square$ Turnover & $100 \%$ & $13 \%$ \\
\hline & $\square$ Liquidity & $67 \%$ & $18 \%$ \\
\hline & $\square$ Solvability & $67 \%$ & $18 \%$ \\
\hline & $\square$ Profitability & $46 \%$ & $24 \%$ \\
\hline & $\square$ EBITDA & $46 \%$ & $24 \%$ \\
\hline & $\square$ Cost of energy, water, waste and transport (\% of turnover) & $35 \%$ & $13 \%$ \\
\hline \multicolumn{4}{|c|}{$\square$ Selling sustainable products/services } \\
\hline & $\square$ Percentage offers with sustainable options & $67 \%$ & $67 \%$ \\
\hline & $\begin{array}{l}\square \text { Share of sustainable products or services in the assortment } \\
\square \text { Percentage of turnover related to sustainable products or } \\
\text { services }\end{array}$ & $\begin{array}{l}46 \% \\
67 \%\end{array}$ & $7 \%$ \\
\hline & $\square$ Share of complaints about products and services & $35 \%$ & $7 \%$ \\
\hline \multicolumn{4}{|c|}{$\square$ Sustainable purchasing } \\
\hline & $\begin{array}{l}\square \text { Purchasing costs of raw materials } x \text { or material y per euro } \\
\text { of turnover } \\
\square \text { Percentage of purchasing budget in which environmental }\end{array}$ & $67 \%$ & $67 \%$ \\
\hline & $\begin{array}{l}\text { and social criteria are assumed } \\
\square \text { Percentage of suppliers and service providers with whom }\end{array}$ & $100 \%$ & $67 \%$ \\
\hline & $\begin{array}{l}\text { agreements are made about environmental and social affairs } \\
\square \text { Share of purchased raw materials that is judged on }\end{array}$ & $46 \%$ & $24 \%$ \\
\hline & presence of dangerous products & $35 \%$ & $18 \%$ \\
\hline \multicolumn{4}{|l|}{ Social } \\
\hline \multicolumn{4}{|l|}{ Security } \\
\hline & $\square$ Number of (near-)accidents without personal damage & $2 \%$ & $2 \%$ \\
\hline & $\square$ Number of accidents with personal damage & $51 \%$ & $2 \%$ \\
\hline
\end{tabular}


$\square$ Number of accidents with work leave

$\begin{array}{rr}18 \% & 2 \% \\ 2 \% & 18 \% \\ 51 \% & 67 \% \\ 100 \% & 100 \% \\ 2 \% & 13 \%\end{array}$

$\square$ Healthy employees

$\square$ Number of dangerous goods in the company

$\square$ Number of IMO containers

$67 \%$

$\square$ Number of improvement points from the annual RI\&E

$13 \%$

$\square$ Percentage of short leave

$2 \% \quad 7 \%$

$\square$ Percentage of medium leave

$18 \%$

$7 \%$

$\square$ Percentage of long leave

$\square$ Happy employees

$\square$ Happiness of employees

$\square$ Percentage of staff turnover

$\square$ Employee training

$\square$ Share of number of hours of training (\% of company hours)

$\square$ Share of number of hours of training focused on sustainability (\% of company hours)

$2 \% \quad 2 \%$

$\square$ Share of training costs in total company costs

$\square$ Percentage of employees that follows individual training

$18 \%$

$\square$ Employee diversity

$\square$ Percentage of women in service
$\square$ Percentage $15-30$ years old
$\square$ Percentage $30-45$ years old
$\square$ Percentage $45-67$ years old
$\square$ Share of employees with less chances on the
employee market (\% of staffing)
$\square$ Share of employees with non-European nationality /
origin

\begin{tabular}{rr}
$18 \%$ & $35 \%$ \\
$2 \%$ & $18 \%$ \\
$2 \%$ & $13 \%$ \\
$2 \%$ & $13 \%$ \\
\hline $100 \%$ & $67 \%$ \\
& \\
$18 \%$ & $24 \%$
\end{tabular}

$\square$ Society

$\square$ Share of local suppliers and/or providers (within a range of $x$ kilometres)

$\square$ Number of complaints about nuisance

$\square$ Share of employees that contribute to annual volunteer activities of the company

$\square$ Share of supplied capital, facilities and human power

Environmental

$\square$ Energy and climate

$$
\begin{aligned}
& \square \text { Electricity usage } \\
& \square \text { Percentage sustainably developed electricity } \\
& \square \text { Percentage sustainably developed heat } \\
& \square \text { Gas or water usage } \\
& \square \mathrm{CO}_{2} \text { emission }
\end{aligned}
$$

$\square$ Waste 
$\square$ Traffic and transport

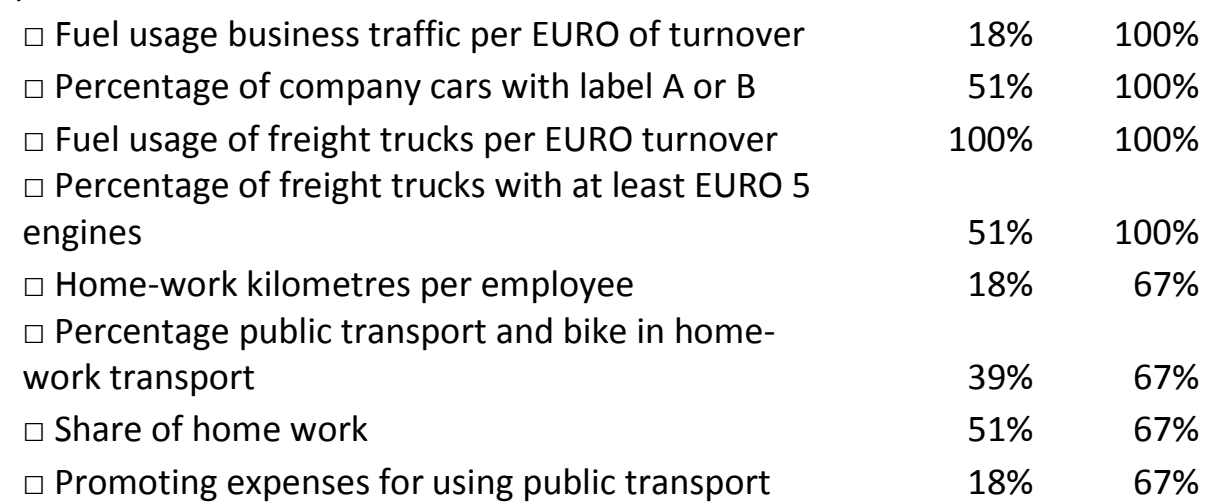

Source: own composition

Overall, when analyzing the descriptive statistics (table 7), we can say that there is relative homogeneity, although very modestly (mean $31.85 \%$ ), in the objective relevance judgement, and relative heterogeneity in the innovation success scoring (mean 34.69\%).

Table 7: Descriptive test statistics

\begin{tabular}{|l|r|c|r|r|r|}
\hline & \multicolumn{6}{|c|}{ Descriptive Statistics } \\
\hline H obj & 56 & .318513 & .3208145 & .0204 & 1.0000 \\
H inno & 56 & .346939 & .3257050 & .0204 & 1.0000 \\
\hline
\end{tabular}

Futhermore, a Wilcoxon ranked sum test was performed to compare consistency between objective relevance scoring and innovation success scoring. It turns out from the resulting $z$ value that the hypothesis that both scorings match well, cannot be rejected at the 0.05 confidence level (table 8). There is therefore no indication that better achieved goals through innovations are not the ones that overall are found most important.

Table 8: Wilcoxon test statistics

\begin{tabular}{|ll|r|r|r|}
\hline & \multicolumn{1}{|c|}{ Ranks } & & Mean Rank & Sum of Ranks \\
\hline \multirow{4}{*}{ H inno - H obj } & Negative Ranks & $18^{\mathrm{a}}$ & 32.03 & 576.50 \\
& Positive Ranks & $34^{\mathrm{b}}$ & 23.57 & 801.50 \\
& Ties & $4^{\mathrm{c}}$ & & \\
& Total & 56 & & \\
\hline
\end{tabular}

a. $\mathrm{H}$ inno $<\mathrm{H}$ obj 
b. $\mathrm{H}$ inno $>\mathrm{H}$ obj

c. $\mathrm{H}$ inno $=\mathrm{H}$ obj

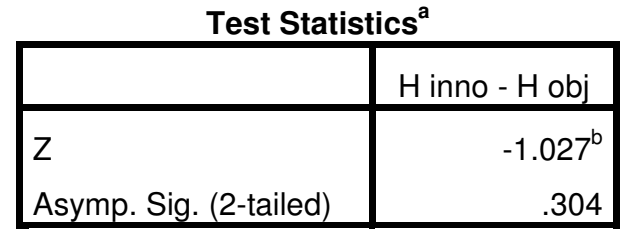

a. Wilcoxon Signed Ranks Test

b. Based on negative ranks.

\section{CONCLUSION}

This paper analysed CSR practice in seaports. It was observed from existing literature that CSR had not really been dealt with in a more or less comprehensive way. The only research to date had analysed in depth partial aspects. In this paper, an effort was made to remedy this. Focus was on portrelated companies in the ports of Antwerp and Rotterdam. A Delphi approach was taken, starting from a list of CSR objectives as applied by Stimular Stichting, but in line with approaches by among others United Nations, OECD and the European Commission. The resulting objective scheme consists of three broad components: economic, social and environmental.

The CSR objective importance scoring given by the interviewed companies shows that overall, social objectives are deemed most important in the companies' CSR policy, followed by economic objectives, and with environmental objectives being least important. The most relevant objectives turn out to be turnover and $\mathrm{CO}_{2}$ emissions. Judged irrelevant with respect to their CSR policies are the 'percentage of purchasing budget in which environmental and social criteria are assumed', 'number of improvement points from the annual RI\&E', 'share of employees with less chances on the employee market', 'share of local suppliers and/or providers', and 'fuel usage of freight trucks per EURO turnover'.

Subsequently, one innovation that was deemed key to each of the seven interviewed companies was tested on its impact success. In line with the relative importance of the three types of objectives, it seems that the social objectives are best achieved, followed by economic and environmental objectives. Best achievable seem the 'number of dangerous goods', 'share of number of hours of training' and 'percentage of employees that follows individual training'. Of the latter, only the 'share of number of hours of training' was deemed very relevant by the companies. Of the objectives judged overall 
very important, only ' $\mathrm{CO}_{2}$ emissions' seems to be very well achieved through innovation initiatives.

Furthermore, homogeneity of the two types of answers was assessed, and compared among each other. It turns out that there is relative homogeneity, although very modestly, in the objective relevance judgement, and relative heterogeneity in the innovation success scoring. Only 'number of improvement points from the annual RI\&E', 'share of local suppliers and/or providers' and 'fuel usage of freight trucks per EURO turnover' do feature full homogeneity for both objective relevance and innovation success. The Wilcoxon rank sum test confirms that there is no deviation overall of both types of homogeneities.

These results give a good first indication of the extent to which CSR is being applied and related innovations are actually successful. The match between the two is rather limited. In order to test whether this remains valid in other contexts, extensions might be required in terms of the number of innovation initiatives, the company scope, the geographical scope and the time scope. Futhermore, it would be interesting to analyse in depth why a certain innovation does not reach the intended objective. These are all possible suggestions for further research.

\section{BIBLIOGRAPHY}

Abreu, M. and Barlow, C. (2013), "A comparative picture of corporate social responsibility approaches by leading companies in the United Kingdom and Brazil", Social Responsibility Journal, Vol. 9, No. 4, pp. 571 - 588.

Barros, C., Felício, J. and Fernandes, R. (2013), "Productivity analysis of Brazilian seaports", Maritime Policy and Management, Vol. 39, No. 5, pp. 503525.

Chang, Y. (2013), "Environmental efficiency of ports: a Data Envelopment Analysis approach", Maritime Policy and Management, Vol. 40, No. 5, pp. 467-478.

Clott, C. and Hartmann, B. (2013), "Clean trucks in California ports: modelling emissions policy", International Journal of Shipping and Transport Logistics, Vol. 5, No. 4, pp. 449-462.

El Abrashi, R. (2011), "Social entrepreneurship theory and sustainable social impact”, Social Responsibility Journal, Vol. 9, No. 2, pp. 188-209 
European Commission (2011), "Communication from the Commission to the European Parliament, the Council", The European Economic and Social Committee and the Committee of the Regions: A renewed EU strategy 201114 for Corporate Social Responsibility, Brussels.

Felicio, J. and Calderinha, V. (2013), "The influence of the characterisation factors of the European ports on operational performance: conceptual model testing", International Journal of Shipping and Transport Logistics, Vol. 5, No. 3, pp. 282-302.

Gill, F. (2012), "Practicing environmental responsibility: local and global dimensions", Social Responsibility Journal, Vol. 8, No. 1, pp. 21-32.

Haralambides, H. and Gujar, G. (2013), "On balancing supply chain efficiency and environmental impacts: An eco-DEA model applied to the dry port sector of India", Maritime Economics and Logistics, Vol. 14, No. 1, pp. 122-137.

Homsombat, W., Leung Yip, T., Yang, H. and Fu, X. (2013), "Regional cooperation and management of port pollution", Maritime Policy and Management, Vol. 40, No. 5, pp. 439-450.

lannone, F. (2013), "A model optimizing the port-hinterland logistics of containers: The case of the Campania region in Southern Italy", Maritime Economics and Logistics, Vol. 14, No. 1, pp. 33-72.

International Organization for Standardization (2013), "Schematic Overview of ISO 26000", Geneva.

Lam, J. and Gu, Y. (2013), "Port hinterland intermodal container flow optimisation with green concerns: a literature review and research agenda", International Journal of Shipping and Transport Logistics, Vol. 5, No. 3, pp. 257-281.

Lauesen, L. M. (2013), "CSR in the aftermath of the financial crisis", Social Responsibility Journal, Vol. 9, No. 4, pp. 641-663.

Lee, S., Tongzon, J. and Chang, Y. (2013), "Assessing port service quality by process component: the case of Korean and Chinese ports", International Journal of Shipping and Transport Logistics, Vol. 5, No. 2, pp. 137-154.

Malik, M. (2013), "Corporate Social Responsibility: A Brief Review of Contemporary Literature", Boston.

OECD (2011), "Guidelines for Multinational Enterprises", Paris. 
Moura-Leite, R. C. and Padgett, R. C., (2011), "Historical background of corporate social responsibility", Social Responsibility Journal, Vol. 7, No. 4, pp. $528-539$.

Schøyen, H. and Odeck, J. (2013), "The technical efficiency of Norwegian container ports: A comparison to some Nordic and UK container ports using Data Envelopment Analysis (DEA)", Maritime Economics and Logistics, Vol. 15, No. 2, pp. 197-221.

Stichting Stimular (2013), "Handleiding MVO-Balans", Rotterdam.

United Nations Global Compact Office (2010), "United Nations Global Compact Annual Review - Anniversary Edition - June 2010", New York. 